University of Nebraska - Lincoln

DigitalCommons@University of Nebraska - Lincoln

Publications, Agencies and Staff of the U.S.

Department of Commerce

U.S. Department of Commerce

2011

Defining bottlenose dolphin (Tursiops truncatus) stocks based on environmental, physical, and behavioral characteristics

Jacalyn L. Toth

Rutgers University, toth@marine.rutgers.edu

Aleta A. Hohn

NOAA

Kenneth W. Able

Rutgers University

Antoinette M. Gorgone

NOAA

Follow this and additional works at: https://digitalcommons.unl.edu/usdeptcommercepub

Part of the Environmental Sciences Commons

Toth, Jacalyn L.; Hohn, Aleta A.; Able, Kenneth W.; and Gorgone, Antoinette M., "Defining bottlenose dolphin (Tursiops truncatus) stocks based on environmental, physical, and behavioral characteristics" (2011). Publications, Agencies and Staff of the U.S. Department of Commerce. 320.

https://digitalcommons.unl.edu/usdeptcommercepub/320

This Article is brought to you for free and open access by the U.S. Department of Commerce at DigitalCommons@University of Nebraska - Lincoln. It has been accepted for inclusion in Publications, Agencies and Staff of the U.S. Department of Commerce by an authorized administrator of DigitalCommons@University of Nebraska - Lincoln. 
MARINE MAMMAL SCIENCE, **(*): ***_***(***2011)

(C) 2011 by the Society for Marine Mammalogy

DOI: $10.1111 /$ j.1748-7692.2011.00497.x

\title{
Defining bottlenose dolphin (Tursiops truncatus) stocks based on environmental, physical, and behavioral characteristics
}

\section{JACALYN L. TOTH}

Marine Field Station, Institute of Marine and Coastal Sciences,

Rutgers University, c/o 132 Great Bay Boulevard, Tuckerton, New Jersey 08087-2004, U.S.A.

E-mail: toth@marine.rutgers.edu

\section{Aleta A. HoHN}

NOAA, National Marine Fisheries Service, Southeast Fisheries Science Center at the NOAA Beaufort Laboratory, 101 Pivers Island Road, Beaufort, North Carolina 28516, U.S.A.

\section{KENNETH W. ABLE}

Marine Field Station, Institute of Marine and Coastal Sciences,

Rutgers University, c/o 132 Great Bay Boulevard, Tuckerton, New Jersey 08087-2004, U.S.A.

\section{ANTOINETTE M. GORGONE}

NOAA, National Marine Fisheries Service, Southeast Fisheries Science Center at the NOAA Beaufort Laboratory, 101 Pivers Island Road, Beaufort, North Carolina 28516, U.S.A.

\begin{abstract}
The population structure of bottlenose dolphins, Tursiops truncatus, along the U.S. Atlantic coast has recently been redefined from one homogenous population into five coastal stocks. Local studies indicate even finer structure, primarily based on isolation of dolphins inhabiting estuaries. We identified population structuring of non-estuarine coastal bottlenose dolphins during a study in New Jersey, the northern range along the Atlantic Coast. Using photo-identification and distribution survey results, an analysis identified two major clusters of individuals significantly separated by five variables (distance from shoreline, group size, occurrence of the barnacle Xenobalanus globicipitis, avoidance behavior, and individual coloration). Sightings assigned to cluster 1 occurred in nearshore shallow waters $(0-1.9 \mathrm{~km}, \bar{x}=$ $3.5 \mathrm{~m}$ ), and those assigned to cluster 2 occurred further offshore in deeper waters
\end{abstract}


(1.9-6 km, $\bar{x}=9.5 \mathrm{~m}$ ). Only eight of 194 individuals (4\%) were identified in both regions. Collectively, this suggests an occurrence of two stocks that are spatially, physically, and behaviorally distinguishable over a small distance. These results indicate that complexity in Tursiops population structure is not limited to latitudinal gradients or barriers created by estuarine habitats, but also by partitioning of habitat as a function of distance from shore and depth over small distances.

Key words: bottlenose dolphin, Tursiops truncatus, New Jersey, population unit, stock structure, Xenobalanus, photo-identification.

Increasing emphasis on determining population structure within species, to both improve management and better understand biology, has frequently resulted in complex partitioning of animal populations. Various levels of population structuring have been shown to occur in animal species that live sympatrically, including fishes (Lear 1984, Kinsey et al. 1994, Moore and Bronte 2001, Alfonso 2004, Hoff 2004), cetaceans (see Hoelzel et al. 2002, Natoli et al. 2004, Rosel et al. 2009 and references therein), birds (Baker et al. 1995, Baker and Logue 2003), and large terrestrial mammals (Prithiviraj et al. 2000, Mauritzen et al. 2002, Paetkau et al. 2008). Despite their mobile nature, tendency to migrate, and the lack of spatial barriers to genetic dispersal, structuring is seen in many animal populations (see prior citations) through differences in morphological characteristics, hemoglobin characteristics, habitat selection, social structure, contaminant and parasite loads, stable isotope ratios, diet, and genetic structure.

Cetacean population structuring, based on genetic and morphological studies in both coastal and pelagic environments, has become increasingly evident (Baird and Dill 1995, Wells et al. 1999, Hoelzel et al. 2002, Secchi et al. 2003, Natoli et al. 2004, Sanino et al. 2005, Sellas et al. 2005, Segura et al. 2006, Bilgmann et al. 2007, Chivers et al. 2007, Hoelzel et al. 2007, Foote et al. 2009, Mirimin et al. 2009, Mendez et al. 2010). In addition to structuring that occurs in cetaceans with broad distributions, studies suggest that it can also occur in populations that remain in relatively limited geographic areas despite the lack of a barrier to movement. For example, in the northeast Pacific Ocean, at least three sympatric killer whale, Orcinus orca, ecotypes are genetically discrete, differ in habitat use and foraging patterns, as well as social and behavioral organization (Bigg et al. 1987, 1990, Baird and Dill 1995, Jones 2006, Hoelzel et al. 2007). So-called "transient" killer whales forage primarily on marine mammals and have distinctly separate movement patterns than fish-eating "resident" and "offshore" killer whales (Bigg et al. 1987, 1990, Baird and Dill 1995, Jones 2006). Similarly, in a portion of the western south Atlantic off of Argentina, Brazil, and Uruguay, the endemic franciscana, Pontoporia blainvellei, is described by two disjunct populations that differ in distribution, contaminant and parasite loads, as well as in phenotype, genotype, and environmental characteristics (Secchi et al. 2003, Mendez et al. 2010). In both cases, although these ecotypes exhibit some level of spatial overlap and genetic dispersal possible, they are commonly differentiated as distinct populations.

Bottlenose dolphins, Tursiops truncatus, which occur along the east coast of the United States, are no exception to complex population structuring (Rosel et al. 2009). Initial attempts to delineate spatial boundaries, including aerial surveys, photoidentification, genetic sampling, isotopic ratio analysis, diet analysis, and satellitelinked radio tag telemetry, led to the designation of seven distinct "management 
units" from New Jersey to Florida, with recent revisions resulting in five coastal stocks. These stocks differ in abundance, migratory patterns, stable isotope ratios, and display varying degrees of genetic differentiation (Hohn 1997, Rosel et al. 2009). Furthermore, "inshore" bottlenose dolphins occur primarily in estuarine systems year-round along more southern portions of the east coast of the United States (e.g., Gubbins 2002, Zolman 2002). The degree of movement and genetic exchange between dolphins inhabiting different estuarine systems, as well as between these inshore dolphins and those inhabiting adjacent coastal areas, is limited (e.g., Caldwell 2001, Sellas et al. 2005, Fazioli et al. 2006, Rosel et al. 2009).

New Jersey is the northernmost regular occurrence of western Atlantic coastal bottlenose dolphins, which range from southern New York to southern Florida. Bottlenose dolphins occur in New Jersey from approximately May through early October and migrate to southern coastal or more offshore regions during winter months (Hohn 1997, Toth et al. 2011). These animals comprise the currently defined northern migratory stock of bottlenose dolphins. Although their seasonal use of New Jersey waters has received recent attention (Toth et al. 2011), little else is known about bottlenose dolphins that occur in New Jersey. This population is different from other bottlenose dolphin populations along the U.S. east coast in that they do not commonly occur in estuaries, even on a seasonal basis (Toth et al. 2011). We investigated the possibility that bottlenose dolphins inhabiting New Jersey might, indeed, show more population structure than currently defined, and attempted to identify factors useful in defining that structure.

\section{Materials AND METHODS}

The primary study area consisted of 70 linear $\mathrm{km}\left(\sim 420 \mathrm{~km}^{2}\right)$ of nearshore waters, extending 0-6 km from shore (depth range $0.5-17 \mathrm{~m}$ ), from the northern tip of Long Beach Island to southern Longport, New Jersey, as well as eight linear kilometers within the adjacent Great Bay estuary (Fig. 1). Bathymetry off Long Beach Island has a relatively steep slope that drops off to 10-14 m within approximately $2 \mathrm{~km}$ from the coast and 16-17 m within $6 \mathrm{~km}$ of the coast. Off Little Beach, Brigantine, and Atlantic City, there is a gentler slope that drops to 6-8 $\mathrm{m}$ within approximately $2 \mathrm{~km}$ from the coast, and 12-13 m within $6 \mathrm{~km}$ of the coast. For surveying purposes, the study site was separated into $0-2 \mathrm{~km}$ and $2-6 \mathrm{~km}$ study areas, with northern (36 linear $\mathrm{km}, 216 \mathrm{~km}^{2}$ ) and southern strata $\left(34\right.$ linear $\mathrm{km}, 204 \mathrm{~km}^{2}$ ) (Fig. 1).

\section{Survey Method}

Surveys were conducted weekly, conditions permitting, from May through October in 2005 from 0 to $6 \mathrm{~km}$ from shore. On every survey day, the northern or southern portion of the $0-2 \mathrm{~km}$ or $2-6 \mathrm{~km}$ study area was chosen at random. Two strip transect lines were surveyed with a random northern or southern starting point; both lines could be surveyed in $1 \mathrm{~d}$. If sea-state conditions deteriorated to greater than a Beaufort 3, the survey was terminated. If photographs and data were taken while actively searching for dolphins at any point during the survey, the data were used in the analysis.

Surveys were conducted from an outboard powered boat $(5 \mathrm{~m})$ with three personnel on board (boat driver, photographer, and data recorder). When conditions allowed, the 


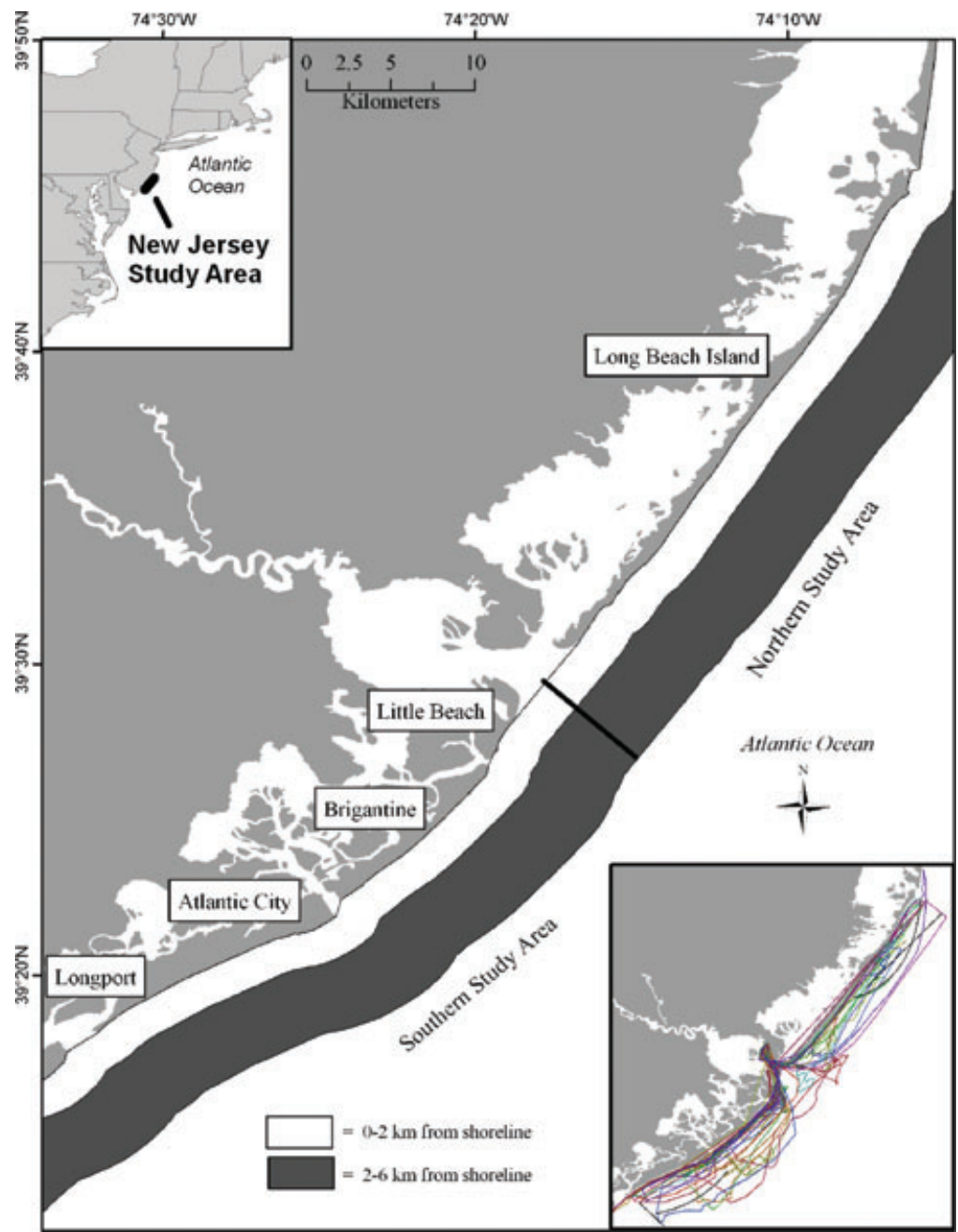

Figure 1. Southern New Jersey study area indicating areas 0-2 km from shore, 2-6 km from shore, the northern $(36 \mathrm{~km})$ and southern $(34 \mathrm{~km})$ sections of the study area, and the track lines surveyed.

boat was driven at a speed of $10-14 \mathrm{~km} / \mathrm{h}$ until bottlenose dolphins were encountered. Upon a sighting, the boat was slowed to a speed of $1-5 \mathrm{~km} / \mathrm{h}$ and maneuvered to within 50-75 m of the group. "Groups" were defined as any individuals in proximity to one another, usually but not always, moving in the same direction and engaged in similar behaviors. Because it was common for groups to break up, form smaller groups, and then reunite, groups that remained within approximately $500-600 \mathrm{~m}$ of one another were considered the same group (Defran and Weller 1999). Each sighting represented a group of individuals encountered at a particular latitude and longitude; the recorded variables for a particular sighting were assumed to be representative of the entire group. The time and latitude/longitude of each group 
encountered were recorded with a Garmin GPS 12XL (Garmin International, Inc., $\mathrm{KS})$.

We attempted to photograph the dorsal fin of each dolphin encountered. Photographs were taken using a Canon Digital 10D SLR camera with a 100-300 mm lens. The boat approached the back of the group and moved forward to the front of the group until all individuals were photographed. Attempts to photograph a group were terminated after $45 \mathrm{~min}$ if the boat could not be maneuvered into position because of the dolphins' avoidance behavior. The time, location, and minimum/maximum/ best estimate of group size were recorded when photographic efforts were concluded.

Individual photographs were cropped in Adobe Photoshop Elements, assigned a photo-grade based on methods previously described (see Urian et al. 1999, Friday et al. 2000, Read et al. 2003 for specific details), and entered into the program Finscan 1.6.1. (Hillman et al. 2003). If multiple photographs of one individual were taken during an encounter, the photograph with the highest quality was used. Matches were reviewed and agreed upon by two experienced observers.

\section{Environmental, Physical, and Behavioral Data}

In addition to latitude, longitude, distance from shoreline, and group size, other variables recorded for each sighting included sea surface temperature and salinity, Beaufort Sea State, wave height, water depth, number of subgroups, relative color of the individuals, percent of the group with the barnacle Xenobalanus globicipitis (a potentially useful marker for certain dolphin populations, Toth-Brown and Hohn 2007), number of young-of-the-year and neonates, and the initial avoidance behavior of the group. Final observations were made by the same observer in order to reduce variability in assigning categories. The occurrence of $X$. globicipitis was recorded as a percentage of the individuals within a group that carried the barnacle. Neonates were defined by their small size, dark gray coloration, lightly pigmented epithelium from fetal folds, and the presence of a floppy dorsal fin. Young-of-year (YOY) were approximately one-half to three-quarters the size of an adult, lighter in color than neonates and may, but not always, have had pigmented epithelium from fetal folds (Fernandez and Hohn 1998). Behavior was noted as "avoidance" if the dolphin group was elusive, such as an increase in swimming speed for a prolonged period and/or if the vessel could not approach the group to within approximately 50-75 m. The relative coloration of individuals within the group was recorded as a "base coloration" or "lighter coloration." This "base coloration" was determined by the same lead observer in all surveys conducted in the 0-2 km study area 2003-2004, and again in 2005 (in order to provide consistency in this subjective measure). Surface temperature and salinity were recorded with a salinometer (YSI handheld instrument) at the beginning of each sighting.

\section{Data Analyses}

Sightings of bottlenose dolphins (hereafter "dolphins") were pooled by week for data analysis and statistical purposes. Sightings-per-unit-effort (SPUE) was calculated to standardize unequal effort among survey areas. Effort was measured as kilometers traveled while actively searching for dolphins (Reilly and Fiedler 1994). Difference 
Table 1. Summary of monthly survey effort in 2005 and number of individuals identified.

\begin{tabular}{lcc}
\hline \hline Survey month & Survey effort $(\mathrm{km})$ & Newly identified \\
\hline 0-2 km from shore & 327 & \\
June & 502 & 15 \\
July & 282 & 51 \\
August & 159 & 1 \\
September & 135 & 0 \\
October & 1,052 & 93 \\
Total & 256 & 13 \\
2-6 km from shore & 334 & 50 \\
June & 132 & 39 \\
July & 722 & 101 \\
August & & \\
Total & & \\
\hline
\end{tabular}

in the SPUE between the $0-2 \mathrm{~km} v$ s. 2-6 $\mathrm{km}$ study areas was compared using a one-way analysis of variance.

"Distance from shoreline" was recorded as the distance from the shoreline, in meters, at which the group was encountered and was obtained using sighting latitude/longitude and distance tools in ArcMap 9.0. Relative dolphin coloration, YOY and neonate presence/absence, and avoidance behavior was recorded as 0 or 1 , respectively (base coloration or lighter coloration, absent or present, indifference or avoidance). All categorical data were log-transformed for analysis. Because there were no a priori designations of dolphin groups encountered, a cluster analysis (Ward's method, McGarigal et al. 2000) was performed on a total of 42 sightings to examine the possibility of natural groupings according to their distance from shoreline. After obtaining these results, the average linkage method was run on the same data set to examine the consistency of the clusters formed by the two different clustering methods (McGarigal et al. 2000). This approach can help determine the validity of formed clusters. Following the cluster analysis based on distance from shoreline, a discriminant function analysis (DFA) was used to identify which of the remaining eight environmental, behavioral, or physical variables provided the most discrimination between the defined cluster analysis groupings. These were then ranked in order of discriminating power. The means of all variables were then calculated for each cluster, and compared using a multivariate analysis of variance. The Graphical Information System Arcmap 9.0 was used to display maps of the study site, latitude/longitude positions of dolphin occurrence, and location of dolphin groups as denoted by the cluster analysis.

\section{RESULTS}

A total of 29 surveys were conducted May-October in 2005. Of these surveys, 28 were included in the analysis and one was discarded due to inclement weather (Table 1). During these 28 surveys, we searched for $1,776 \mathrm{~km}(181 \mathrm{~h})$ and $1,494 \mathrm{~km}(59 \mathrm{~h})$ were spent in contact with dolphin groups. Sightings occurred during $76 \%$ of surveys $(n=22)$; 42 sightings comprising 981 dolphins were recorded (Fig. 1). SPUE was not significantly different between the $0-2 \mathrm{~km}$ 


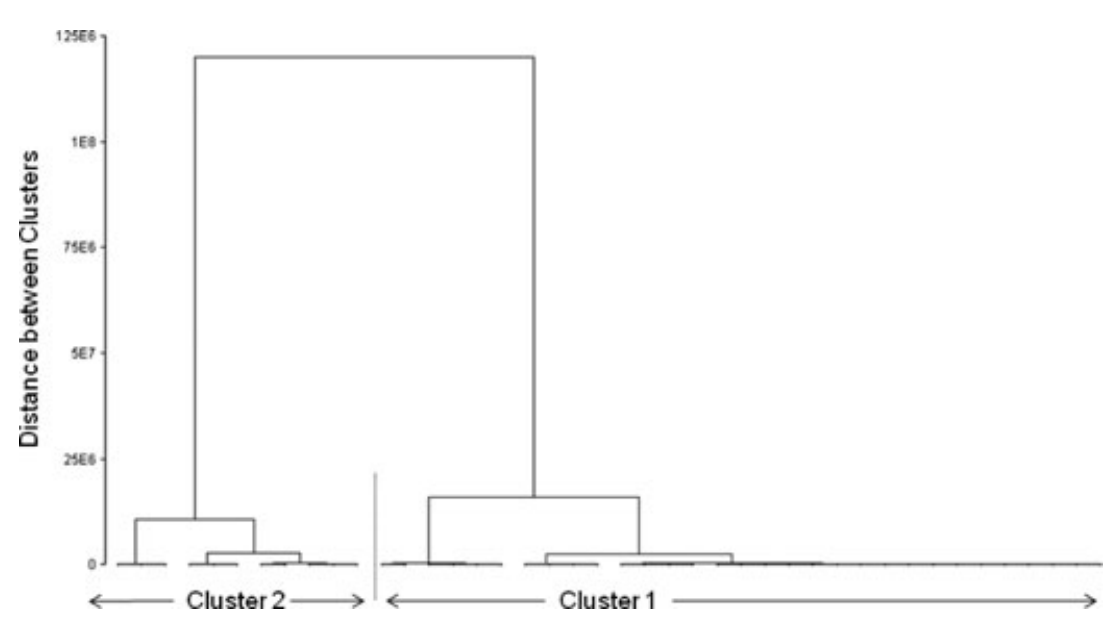

Figure 2. Dendrogram of cluster analysis based on 42 bottlenose dolphin sightings in 2005. A total of 25 sightings were assigned to cluster 1 and 17 were assigned to cluster 2 .

(0.037 sightings $/ \mathrm{km})$ and the $2-6 \mathrm{~km}$ study areas $(0.028$ sightings $/ \mathrm{km})$. A total of 194 individuals were identified 256 times, with a maximum of four sightings for four individuals.

\section{Environmental, Physical, and Behavioral Characteristics}

From the 42 sightings analyzed in the cluster analysis, two major clusters were identified based on the variable distance from shoreline; 25 sightings were assigned to cluster 1 ( $\mathrm{C} 1$ population unit) and the remaining 17 sightings were assigned to cluster 2 (C2 population unit) (Fig. 2). All 25 sightings assigned to $\mathrm{C} 1$ occurred within 0-1.9 km offshore, and all 17 sightings assigned to C2 occurred within $1.9-6 \mathrm{~km}$ offshore. With the exception of one sighting, Ward's and the average linkage method rendered the same resultant clusters, indicating that the clusters were valid (McGarigal et al. 2000).

From the DFA that included the remaining eight environmental/ behavioral/physical variables, the eigenvalue $(0.91)$ associated with canonical function 1 was significant $(f=3.78, P<0.0030)$. The linear combination of variables in canonical function 1 described $91 \%$ of the variation between clusters. The eigenvectors most highly associated with canonical function 1 were percent of the group with $X$. globicipitis (0.93), group size (0.54), and relative coloration $(0.50)$, and initial avoidance behavior $(0.47)$ (Table 2$)$. When the discriminant function canonical scores are plotted according to this linear combination of variables, the separation between clusters is apparent; although a small number of sightings in $\mathrm{C} 1$ and $\mathrm{C} 2$ overlap, these clusters generally exhibit a spatial separation (Fig. 3). Similarly, when each sighting is assigned to its respective cluster and plotted spatially within the study area, this same separation is apparent (Fig. 4).

There were no significant differences in the mean values of temperature $(P=$ $0.4404)$, salinity $(P=0.2426)$, presence/absence of neonates $(P=0.0714)$, or YOY individuals $(P=0.3359)$ between clusters (Table 2$)$. Average distance from the shore was significantly different $(P=0.0001)$; dolphins in $\mathrm{C} 1$ occurred an average of 
Table 2. Discriminant function analysis and analysis of variance summary statistics of variable means $\pm \mathrm{SE}$ associated with bottlenose dolphin groups designated to cluster 1 or cluster 2 .

\begin{tabular}{lcccc}
\hline \hline Variable & $\begin{array}{c}\text { Eigenvector } \\
\text { score }\end{array}$ & $\begin{array}{c}\text { Cluster 1 } \\
\text { means }\end{array}$ & $\begin{array}{c}\text { Cluster 2 } \\
\text { means }\end{array}$ & $P$ \\
\hline Distance offshore & & $428.1 \pm 28.7$ & $3,783.6 \pm 371.0$ & 0.0001 \\
Percent of group with barnacle & 0.9277 & $29.2 \pm 3.6$ & $81.6 \pm 5.6$ & 0.0001 \\
Coloration & 0.5019 & $0.01 \pm 0.08$ & $0.23 \pm 0.01$ & 0.0243 \\
Group size & 0.5463 & $11.1 \pm 0.9$ & $41.4 \pm 11.7$ & 0.0136 \\
Avoidance behavior & 0.4657 & $0.08 \pm 0.02$ & $0.32 \pm 0.09$ & 0.0375 \\
Temperature & 0.1111 & $20.6 \pm 3.2$ & $21.3 \pm 3.5$ & 0.4404 \\
Salinity & 0.1802 & $29.4 \pm 2.7$ & $29.8 \pm 0.8$ & 0.2426 \\
Young-of-year-presence & 0.2132 & $0.13 \pm 0.05$ & $0.20 \pm 0.11$ & 0.3359 \\
Neonate presence & 0.3012 & $0.07 \pm 0.04$ & $0.17 \pm 0.10$ & 0.0714 \\
\hline
\end{tabular}

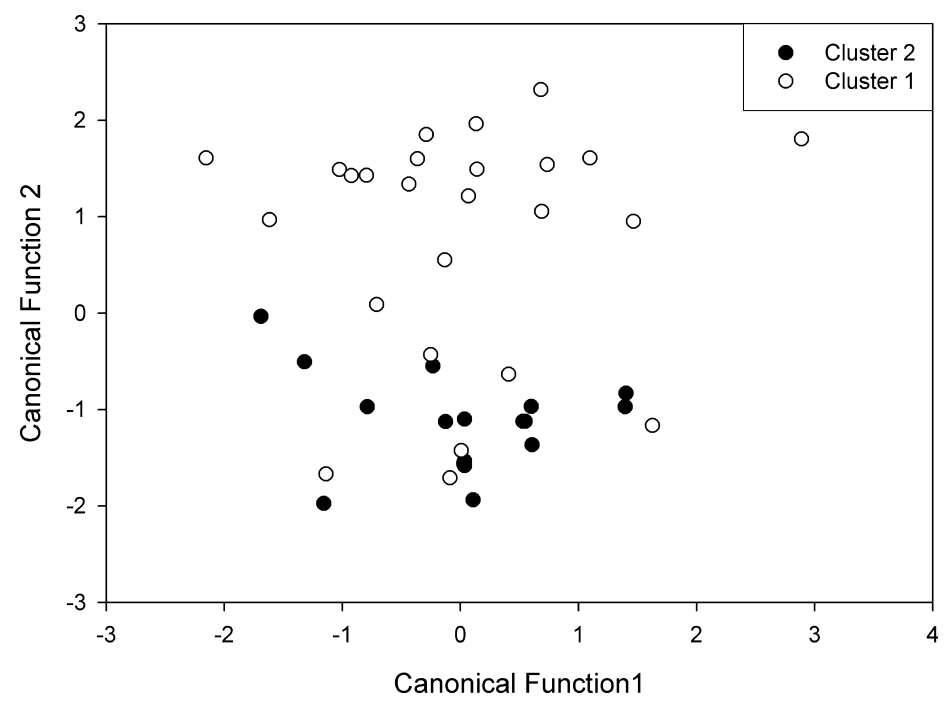

Figure 3. Distribution of bottlenose dolphin clusters 1 and 2 according to the linear combination of contributing variables determined by the discriminant function analysis.

$428.1 \pm 28.7 \mathrm{~m}$ from the shore in $3.5 \pm 0.32 \mathrm{~m}$ water depth, while individuals in C2 occurred an average of $3,783.6 \pm 371.0 \mathrm{~m}$ from the shore in $9.6 \pm 1.2 \mathrm{~m}$ water depth. The percent of $X$. globicipitis within each group was significantly different between clusters $(P=0.0001)$. In $\mathrm{C} 1,29 \% \pm 3.6 \%$ of the individuals within a given group carried $X$. globicipitis, while in C2, $81 \% \pm 5.6 \%$ of individuals within a given group carried $X$. globicipitis. Difference in average dolphin group size was significant as well $(P=0.0136)$, as $C 1$ groups averaged $11.1 \pm 0.9$ individuals and $\mathrm{C} 2$ groups averaged $41.4 \pm 11.7$ individuals. Finally, relative coloration $(P=$ $0.0243)$ and avoidance behavior $(P=0.0375)$ were significantly different between clusters. Groups in C1 averaged close to the base coloration $(\bar{x}=0.01 \pm 0.08)$ and generally displayed indifferent behavior to the presence of the boat $(\bar{x}=0.08 \pm$ $0.02)$. Groups in $\mathrm{C} 2$ averaged a lighter coloration $(\bar{x}=0.23 \pm 0.01)$ and generally exhibited avoidance behavior $(\bar{x}=0.32 \pm 0.09)$. 


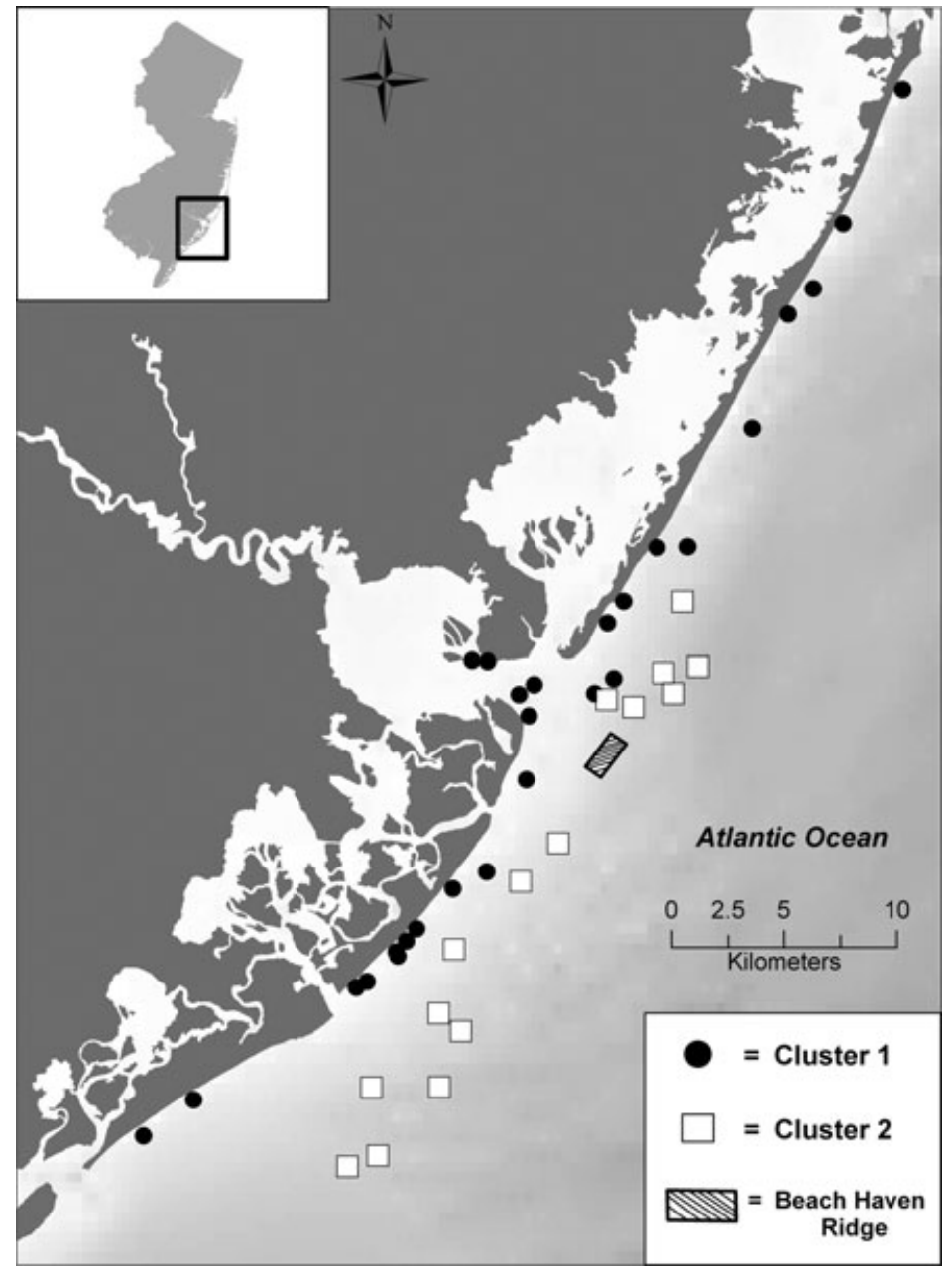

Figure 4. Distribution of bottlenose dolphin groups assigned to clusters 1 and 2 in the study area. From 42 sightings analyzed, all sightings that occurred within $1.9 \mathrm{~km}$ of shoreline were assigned to cluster $1(n=25)$, and all sightings that occurred beyond $1.9 \mathrm{~km}$ from shoreline were assigned to cluster $2(n=17)$.

\section{Resightings}

The distribution of the two population units (C1 and C2) was supported by the pattern of resightings of individual dolphins. A total of 194 individuals were identified and sighted 256 times throughout the entire study area, with a maximum of four sightings for four individuals. Of these, 89 individuals were first identified in the $0-2 \mathrm{~km}$ study area, and 105 individuals in the $2-6 \mathrm{~km}$ area. While 43 total individuals were sighted multiple times, only eight $(4 \%)$ were sighted in both the $0-2 \mathrm{~km}$ and $2-6 \mathrm{~km}$ study areas. These eight individuals occurred in four groups and were seen from 260 to 3,236 m offshore in 1.6-10.3 m depth. Of these eight 
individuals seen in both the $0-2 \mathrm{~km}$ and $2-6 \mathrm{~km}$ region, five were sighted together in the coastal-shallow area one time (of 2-4 sightings each), two were sighted together in both the 0-2 km and 2-6 km study area (with a difference of $2 \mathrm{~d}$ ), and one was never sighted with another individual that was identified in both regions. All four groups exhibited light coloration and avoidance behavior characteristics of $\mathrm{C} 2$, but had low percentages of $X$. globicipitis consistent with C1.

\section{DisCUSSION}

The available data suggest that bottlenose dolphins inhabiting coastal waters of New Jersey comprise (at least) two stocks in the summer. While population differentiation of cetaceans is often based on mitochondrial DNA, microsatellite DNA, and individual identification of morphological characteristics (Dowling and Brown 1993, Natoli et al. 2004, Parsons et al. 2006, Möller et al. 2007, Foote et al. 2009, Perrin et al. 2010), this study suggests that patterns of movement, coloration, behavior, and environmental characteristics may provide other useful approaches in addressing questions of population structure and, at a minimum, help focus where genetic studies might be conducted. Because the New Jersey sightings clustered primarily by distance from shore (and therefore water depth), hereafter we will refer to dolphins that occurred $0-1.9 \mathrm{~km}(\sim 1-7 \mathrm{~m}$ depths $)$ as the "coastal-shallow" unit and those that occurred 1.9-6 km from shore ( 6-15 m depths) as the "coastal-deep" unit.

\section{Environmental, Physical, and Behavioral Characteristics}

The variables group size, percent of $X$. globicipitis, relative coloration, and avoidance behavior were significant components of the variance between clusters. These results suggest that, used in combination with each other and distance from shore, these variables may be accurate predictors of population unit membership in New Jersey. Of all the variables that contributed to the variance between clusters, the least is known about the relationship of the pseudostalked barnacle, $X$. globicipitis, to bottlenose dolphins. Though $X$. globicipitis occurrence is widespread and has been reported in many cetacean species, the mechanism that drives its occurrence remains largely unknown (Orams and Shuetze 1998, Aznar et al. 2001, Fertl 2002, Toth-Brown and Hohn 2007, Kane et al. 2008). The pattern of occurrence of X. globicipitis in New Jersey, however, is consistent.

A number of factors have been suggested to affect the settlement of X. globicipitis, including host swimming speed, low immunity due to the age or health of the animal, upwelling events, and water temperature (VanWaerebeek et al. 1993, Orams and Shuetze 1998, Aznar et al. 2001, Fertl 2002, Kane et al. 2008). Although results may vary depending on the geographic region, Toth-Brown and Hohn (2007) found that, overall, the relative number of $X$. globicipitis occurring on individual bottlenose dolphins was stable both within and among years during the summer months in New Jersey. Because patterns of barnacle occurrence are unknown or vary geographically, further research on $X$. globicipitis larval distribution, spawning, settlement, and effect of oceanic processes is necessary to make definitive conclusions about its relevance to identification of population units. If these patterns in X. globicipitis on New Jersey bottlenose dolphins are found to be consistent spatially and temporally, this could 
potentially be a useful marker of unit membership in more southern areas along the east coast.

Avoidance behavior was also significantly different between dolphins in coastalshallow and coastal-deep regions. While groups encountered in the coastal-deep area actively avoided the research boat, groups in the coastal-shallow area generally did not display avoidance behaviors. Studies on the effects of boating interaction on cetacean behavior report a variety of potential reactions including unpredictable group movements, change in swimming speed, longer dive times, and change in respiration patterns (Nowacek et al. 2001, Lusseau 2003). These reactions vary with boater movements, the number of boats, and the speed at which boats approach (Nowacek et al. 2001). In Doubtful Sound, New Zealand, Lusseau (2003) found that if cautionary movement guidelines were followed, dolphins did not alter their behavior or show signs of boat avoidance. In the current study, the single dolphinwatching tour boat within the $0-2 \mathrm{~km}$ study area was consistently observed to be cautious and unobtrusive, especially around groups of dolphins with neonates. This may have allowed individual dolphins to become habituated over several years to vessels that were more predictable in their movements, including our research boat (see Toth et al. 2011). The consistency of an avoidance reaction to boater presence between population units may be, in part, a result of fidelity to a certain region in which the behavior was cultivated.

Group size also differed between coastal-shallow and coastal-deep units. Although variability in dolphin group size may occur (Shane et al. 1986), overall patterns from studies in varied habitats indicate that group size increases with the openness of habitat (Shane et al. 1986, Gygax 2002). In the current study, coastal-deep group sizes were significantly larger than coastal-shallow group sizes. With the exception of the rarely used $8 \mathrm{~km}$ of transect within Great Bay estuary (Toth et al. 2011), both the coastal-shallow and coastal-deep areas are "open" coastal habitat, i.e., not an embayment. Therefore, one would not expect such considerable differences in group size between areas. It is possible, however, that the shallow depths $(2-4 \mathrm{~m})$ throughout some of the $0-2 \mathrm{~km}$ study area dictate smaller group sizes, similar to other studies in shallow habitats such as bays, sounds, and estuaries. Differences in group size are sometimes attributed to a trade-off between the availability of food and the risk of predation (Heithaus and Dill 2002), as well as the availability and distribution of food and the dolphins' adaptations to optimize foraging (Norris and Dohl 1980, Wells et al. 1980). Further study may reveal that these factors play a role in the pattern of group size observed.

Coastal-deep bottlenose dolphins were lighter gray in coloration than what was considered the "base coloration" of individuals derived from studies conducted in 2003-2004 (Toth et al. 2011). In addition to studies that have attributed depigmentation to sexual dimorphism in other cetaceans (Martin and da Silva 2006), difference in pigmentation has also been reported between sympatric species of bottlenose dolphins (genus Tursiops) in China (Wang et al. 2000). In addition, coloration of the killer whale dorsal cape is a distinct and distinguishing feature among ecotypes in antarctic waters (Pitman and Ensor 2003). In conjunction with other features such as size and shape of the cape, varying dorsal cape coloration is indicative of the particular whale ecotype in this study. Although attempts for consistency in this measure were made, the ability to precisely measure coloration is necessary to make definitive statements about the patterns observed in New Jersey. Nonetheless, this preliminary finding is striking when put in context with other covarying variables. 


\section{Resightings}

Of the 194 total individuals identified throughout the 2005 study, only eight $(4 \%)$ were observed in both the coastal-shallow and coastal-deep regions, suggesting fidelity of individuals to either region. It should be noted that during 20032004 photographic studies conducted in the $0-2 \mathrm{~km}$ area (using the same protocol of the current study), an additional 112 individuals were identified (Toth et al. 2011). When these 2003-2004 individuals were included in the resighting analysis, $41(37 \%)$ were sighted in the $0-2 \mathrm{~km}$ study area, while only one $(0.009 \%)$ was sighted in the $2-6 \mathrm{~km}$ study area in 2005 .

Other photographic studies have reported similar patterns of little spatial overlap between dolphin groups in distinct spatial regions (Odell and Asper 1990, Würsig and Lynn 1996, Wells et al. 1999, Gubbins 2002, Zolman 2002, Fazioli et al. 2006, Urian et al. 2009), yet unlike the current study, these included resident bottlenose dolphins that spend much of their lives inside estuaries. In a study that did consider coastal dolphins, Fazioli et al. (2006) provide evidence of two well-defined bottlenose dolphin population units off the coast of Sarasota, Florida; one comprised dolphins that remained in close proximity to estuaries and adjacent coastline ("Inshore" dolphins), and the other comprised dolphins that remained an average of approximately $5 \mathrm{~km}$ offshore ("Gulf" dolphins). Furthermore, genetic analysis determined differentiation between these population units, indicating that individuals within the same unit are more closely related than individuals in two different units, while not unequivocally indicating reproductive isolation.

\section{Factors Influencing Spatial Differentiation}

Various ecological factors are thought to influence intraspecific divergence, including adaptation to selective pressure by local environmental conditions (Dizon et al. 1992, Bearzi 2005), oceanographic processes (Bilgmann et al. 2007), resource specialization, and social structure (Fullard et al. 2000, Sellas et al. 2005). Specifically, population structuring has been attributed to prey availability, dietary divergence, and/or the ability of cetaceans to exploit resources in different ways. For example, a recent study in southwestern Australia (Möller et al. 2007) suggested that in addition to genetic differentiation between bottlenose dolphins that occur within embayments vs. adjacent coastal waters (separated by only tens of kilometers), these populations likely have dietary specializations facilitated by the habitat differences between the two areas. In addition, large populations within a region have been shown to utilize different resources that occur at varying depths. In the killer whale population off of British Colombia, "transient" individuals primarily feed on pinnipeds at haul-out sites and in nearshore waters, while "resident" individuals feed primarily on salmon in the top $20 \mathrm{~m}$ of the water column (Bigg et al. 1987, Baird et al. 2005). At least in the northern area in this New Jersey study, the apparent spatial separation between the coastal-shallow and coastal-deep bottlenose dolphins off the coast occurs approximately at a relatively rapid change in depth about $2 \mathrm{~km}$ from shore.

Furthermore, observations of many cetacean species, including bottlenose dolphins, suggest that cultural transmission of information and behavior may be an important part of ecological and evolutionary development (Hoelzel 1998, Rendell and Whitehead 2001, Wells 2003, Krutzen et al. 2005) and may be related to the spatial and temporal variation in prey items (Barrett-Lennard et al. 2001). Examples of bottlenose dolphin cultural foraging techniques and behavior that may be 
passed through social learning are varied. These can include the use of marine sponges as suspected tools for feeding by female dolphins in Shark Bay, Australia (Smolker et al. 1997, Krutzen et al. 2005, Mann et al. 2008), "strand-feeding" in which groups of dolphins surge onto mudflats in pursuit of prey in the southeastern United States (Rigley 1983, Silber and Fertl 1995), or the consistent exploitation of different prey types in sympatric populations (e.g., salmon vs. pinniped predation in killer whales).

It is possible that cultural transmission of behavior related to foraging and its relationship to spatial partitioning of habitat by bottlenose dolphins plays some role in the patterns seen in the New Jersey study area. Juvenile and adult fishes are known to occur along both the shoreline within the study area (Able et al. 2002, Martino and Able 2003, Wilber et al. 2003), as well as along shoreface sand ridges located 1-6 km offshore (Beach Haven Ridge, see Fig. 3) (McBride and Moslow 1991, Vasslides and Able 2008). Perhaps the availability of prey along sand ridges may allow the coastaldeep unit to occupy a niche slightly offshore and lessen the need to compete for resources more inshore. As seen in other studies, this behavioral plasticity may have led to community specialization over time. Certainly, further research in the New Jersey area will help to clarify patterns found in this study and provide insight into their potential causes and effects.

In summary, the results of the current study provide evidence supporting the existence of two coastal bottlenose dolphin stocks that use inner continental shelf habitat differently in New Jersey. If most individuals do not overlap or do so rarely, differentiation in morphology, behavior, movement patterns, and eventually genetics can occur (Parsons et al. 2006). As with bottlenose dolphins along the southern U.S. Atlantic coast and the Gulf of Mexico, these results suggest a complex structure of bottlenose dolphin stocks at the northern limit of their migratory range and a more complicated structure than has been proposed to date for coastal bottlenose dolphins in the western North Atlantic.

\section{ACKNOWLEDGMENTS}

The authors thank the National Oceanic and Atmospheric Administration, National Marine Fisheries Service, Southeast Fisheries Science Center (SEFSC) and the Rutgers University Marine Field Station (RUMFS), Tuckerton, New Jersey, for funding and support. We also thank members of the Cetacean and Sea Turtle Team (SEFSC at the NOAA Beaufort Laboratory), Stacy Hagan, Jamie Fraser, Steve Zeck, Kieran Lyons (RUMFS), and many other volunteers for their time and assistance with this project. We thank Peter Morin and Eric Archer for discussion and assistance with the statistical analyses. Comments from L. Hansen, R. Baird, and anonymous reviewers improved this manuscript. This research was conducted under NOAA permit \#779-1633-00. This paper is Rutgers University Institute of Marine and Coastal Sciences Contribution No. 2011-3.

\section{Literature CiteD}

Able, K. W., P. Rowe, M. Burlas and D. Byrne. 2002. Use of ocean and estuarine habitats by young-of-year bluefish (Pomotomas saltatrix) in the New York Bight. Fishery Bulletin 101:201-214.

Alfonso, N. R. 2004. Evidence for two morphotypes of lake charr, Salvelinus namaycush, from Great Slave Lake, Northwest Territories, Canada. Environmental Biology of Fishes 71:21-32. 
Aznar, F. J., J. A. Balbuena, M. Fernandez and J. A. Raga. 2001. Living together: The parasites of marine mammals. Pages 385-423 in P. G. H. Evans and J. A. Raga, eds. Marine mammals: Biology and conservation. Plenum Publishers, London, U.K.

Baird, R. W., and L. M. Dill. 1995. Occurrence and behaviour of transient killer whales: Seasonal and pod-specific variability, foraging behaviour and prey handling. Canadian Journal of Zoology 73:1300-1311.

Baird, R. W., M. B. Hanson and L. M. Dill. 2005. Factors influencing the diving behaviour of fish-eating killer whales: Sex differences and diel and interannual variation in diving rates. Canadian Journal of Zoology 83:257-267.

Baker, A. J., C. H. Daugherty, R. Colbournes and J. L. McLennani. 1995. Flightless brown kiwis of New Zealand possess extremely subdivided population structure and cryptic species like small mammals. Proceedings of the National Academy of Science of the United States of America 92:8254-8258.

Baker, M. C., and D. M. Logue. 2003. Population differentiation in a complex bird sound: A comparison of three bioacoustical analysis procedures. Ethology 109:223-242.

Barrett-Lennard, L. G., V. B. Deecke, J. K. B. Ford and H. Yurk. 2001. A sound approach to the study of culture. Behavioral and Brain Sciences 24:325-326.

Bearzi, M. 2005. Dolphin sympatric ecology. Marine Biology Research 1:165-175.

Bigg, M. A., G. M. Ellis, J. K. B. Ford and K. C. Balcomb. 1987. Killer whales-a study of their identification, genealogy and natural history in British Columbia and Washington State. Phantom Press, Nanaimo, BC.

Bigg, M. A., P. F. Olesiuk, G. M. Ellis, J. K. B. Ford and K. C. Balcomb. 1990. Organization and genealogy of resident killer whales (Orcinus orca) in the coastal waters of British Columbia and Washington State. Report of the International Whaling Commission (Special Issue 12):383-405.

Bilgmann, K., L. M. Möller, R. G. Harcourt, S. E. Gibbs and L. B. Beheregaray. 2007. Genetic differentiation in bottlenose dolphins (Tursiops truncatus) from Southern Australia: Association with local oceanography and coastal geography. Marine Ecology Progress Series 341:265-276.

Caldwell, M. 2001. Social and genetic structure of bottlenose dolphin (Tursiops truncatus) in Jacksonville, Florida. Ph.D. dissertation, University of Miami, Miami, FL. 143 pp.

Chivers, S. J., R. W. Baird, D. J. McSweeney, D. L. Webster, M. Nicole and J. C. Salinas. 2007. Genetic variation and evidence for population structure in eastern North Pacific false killer whales (Pseudorca crassidens). Canadian Journal of Zoology 85:783794.

Defran, R. H., and D. W. Weller. 1999. Occurrence, distribution, site fidelity and school size of bottlenose dolphins (Tursiops truncatus) off San Diego, California. Marine Mammal Science 15:366-380.

Dizon, A. E., C. Lockyer, W. F. Perrin, D. P. DeMaster and J. Sisson. 1992. Rethinking the stock concept: A phylogeographic approach. Conservation Biology 6:24-36.

Dowling, T. E., and W. M. Brown. 1993. Population structure of the bottlenose dolphin (Tursiops truncatus) as determined by restriction endonuclease analysis of mitochondrial DNA. Marine Mammal Science 9:138-155.

Fazioli, K. L., S. Hofmann and R. S. Wells. 2006. Use of Gulf of Mexico coastal waters by distinct assemblages of bottlenose dolphins (Tursiops truncatus). Aquatic Mammals 32:212-222.

Fernandez, A., and A. A. Hohn. 1998. Age structure, growth, and calving season of bottlenose dolphins stranded along the east coast of Texas. Fishery Bulletin 96:357365.

Fertl, D. 2002. Barnacles. Pages 75-78 in W. F. Perrin, B. Würsig and J. G. M. Thewissen, eds. Encyclopedia of marine mammals. Academic Press, San Diego, CA.

Foote, A. D., J. Newton, S. B. Piertney, E. Willerslev and M. T. P. Gilbert. 2009. Ecological, morphological and genetic divergence of sympatric North Atlantic killer whale populations. Molecular Ecology 18:5207-5217. 
Friday, N., T. D. Smith, P. T. Stevick and J. A. Allen. 2000. Measurement of photographic quality and individual distinctiveness for the photographic identification of humpback whales, Megaptera novaeangliae. Marine Mammal Science 16:355-374.

Fullard, J. K., G. Early, P. M. Heide-Jorgensen, D. Bloch, A. Rosing-Asvid and W. Amos. 2000. Population structure of long-finned pilot whales in the North Atlantic: A correlation with sea surface temperature? Molecular Ecology 9:949-958.

Gubbins, C. 2002. Use of home ranges by resident bottlenose dolphins (Tursiops truncatus) in a South Carolina estuary. Journal of Mammalogy 83:178-187.

Gygax, L. 2002. Evolution of group size in the superfamily Delphinoidea (Delphinidae, Phocoenidae and Monodontidae): A quantitative comparative analysis. Mammalian Review 32:295-314.

Heithaus, M. R., and L. M. Dill. 2002. Food availability and tiger shark predation risk influence bottlenose dolphin habitat use. Ecology 83:480-491.

Hillman G. R., B. Würsig, G. A. Gailey, et al. 2003. Computer-assisted photo-identification of individual marine vertebrates: A multi-species system. Aquatic Mammals 29:117123.

Hoelzel, A. R. 1998. Genetic structure of cetacean populations in sympatry, parapatry, and mixed assemblages: Implications for conservation policy. Journal of Heredity 89:451458.

Hoelzel, A. R., S. D. Goldsworthy and R. C. Fleischer. 2002. Population genetics. Pages 325-352 in A. R. Hoelzel, ed. Marine mammal biology: An evolutionary approach. Blackwell Science, Oxford, U.K.

Hoelzel, A. R., J. Hey, M. E. Dahlheim, C. Nicholson, V. Burkanov and N. Black. 2007. Evolution of population structure in a highly social top predator, the killer whale. Molecular Biology and Evolution 24:1407-1415.

Hoff, M. H. 2004. Discrimination among spawning aggregations of lake herring from Lake Superior using wholebody morphometric characters. Journal of Great Lakes Research 30:385-394.

Hohn, A. A. 1997. Design for a multiple-method approach to determine stock structure of bottlenose dolphins in the mid-Atlantic. National Oceanic and Atmospheric Administration, Southeast Fisheries Science Center Technical Memorandum, NMFS-SEFSC-401. Miami, FL. 22 pp.

Jones, I. M. 2006. A northeast Pacific offshore killer whale (Orcinus Orca) feeding on a Pacific halibut (Hippoglossus stenolepsis). Marine Mammal Science 22:198200.

Kane, E. A., P. A. Olson, T. Gerrodette and P. C. Fiedler. 2008. Prevalence of the commensal barnacle Xenobalanus globicipitis on cetacean species in the eastern tropical Pacific Ocean, and a review of global occurrence. Fishery Bulletin 106:395-404.

Kinsey, S. T., T. Orsoy, T. M. Bert and B. Mahmoudi. 1994. Population structure of the Spanish sardine Sardinella aurita: Natural morphological variation in a genetically homogeneous population. Marine Biology 118:309-317.

Krutzen, M., J. Mann, M. Heithaus, R. Connor, L. Bejder and B. Sherwin. 2005. Cultural transmission of tool use in bottlenose dolphins. Proceedings from the National Academy of Science 105:8939-8943.

Lear, W. H. 1984. Discrimination of the stock complex of Atlantic cod (Gadus Morbua) off southern Labrador and eastern Newfoundland, as inferred by tagging studies. Journal of Northwest Atlantic Fisheries Science 5:143-159.

Lusseau, D. 2003. Effects of tour boats on the behavior of bottlenose dolphins: Using Markov chains to model anthropogenic impacts. Conservation Biology 17:17851793.

Mann, J., B. L. Sargeant, J. J. Watson-Capps, et al. 2008. Why do dolphins carry sponges? PLoS ONE 3(12):e3868.

Martin, A., and V. da Silva. 2006. Sexual dimorphism and body scarring in the boto (Amazon River dolphin) Inia geoffrensis. Marine Mammal Science 22:25-33. 
Martino, E., and K. W. Able. 2003. Fish assemblages across the marine to low salinity transition zone of a temperate estuary. Estuarine, Coastal and Shelf Science 56:967-985.

Mauritzen, M., A. E. Derocher, Ø. Wiig, S. E. Belikov, A. N. Boltunov, E. Hansen and G. W. Garner. 2002. Using satellite telemetry to define spatial population structure in polar bears in the Norwegian and western Russian arctic. Journal of Applied Ecology 39:79-90.

McBride, R. A., and T. F. Moslow. 1991. Origin, evolution, and distribution of shoreface sand ridges, Atlantic inner shelf, USA. Marine Geology 97:57-85.

McGarigal, K., S. Cushman and S. Stafford. 2000. Multivariate statistics for wildlife and ecology research. Springer-Verlag Publishing, New York, NY.

Mendez, M., H. C. Rosenbaum, A. Subramaniam, C. Yackulic and P. Bordino. 2010. Isolation by environmental distance in mobile marine species: Molecular ecology of franciscana dolphins at their southern range. Molecular Ecology 19:2212-2228.

Mirimin, L., A. Westgate, E. Rogan, P. Rosel, A. Read, J. Coughlan and T. Cross. 2009. Population structure of short-beaked common dolphins (Delphinus delphis) in the North Atlantic Ocean as revealed by mitochondrial and nuclear genetic markers. Marine Biology 156:821-834.

Moore, S. A., and C. R. Bronte. 2001. Delineation of sympatric morphotypes of lake trout in Lake Superior. Transactions of the American Fisheries Society 130:1233-1240.

Möller, L. M., J. Wiszniewski, S. A. Allen and L. B. Beheregaray. 2007. Habitat type promotes rapid and extremely localized genetic differentiation in dolphins. Marine and Freshwater Research 58:640-648.

Natoli, A., V. M. Peddemors and M. Hoss. 2004. Population structure and speciation in the genus Tursiops based on microsatellite and mitonchondrial DNA analyses. Journal of Evolutionary Biology 17:363-375.

Norris, K. S., and T. P. Dohl. 1980. The structure and functions of cetacean schools. Pages 211-261 in L. M. Herman, ed. Cetacean behavior: Mechanisms and functions. John Wiley and Sons, New York, NY.

Nowacek, S. M., R. S. Wells and A. R. Solow. 2001. Short-term effects of boat traffic on bottlenose dolphins, Tursiops truncatus, in Sarasota Bay, Florida. Marine Mammal Science 17:673-688.

Odell, D. K., and E. D. Asper. 1990. Distribution and movements of freeze-branded bottlenose dolphins in the Indian and Banana rivers, Florida. Pages 515-540 in S. Leatherwood and R. R. Reeves, eds. The bottlenose dolphin. Academic Press, San Diego, CA.

Orams, M. B., and C. Schuetze. 1998. Seasonal and age/size-related occurrence of a barnacle (Xenobalanus globicipitis) on bottlenose dolphins (Tursiops truncatus). Marine Mammal Science 14:186-189.

Paetkau, D., W. Calvert, I. Stirling, and C. Strobeck. 2008. Microsatellite analysis of population structure in Canadian polar bears. Molecular Ecology 4:347-354.

Parsons, K. W., J. W. Durban, D. E. Claridge, D. L. Herzing, K. C. Balcomb and L. R. Noble. 2006. Population genetic structure of coastal bottlenose dolphins (Tursiops truncatus) in the northern Bahamas. Marine Mammal Science 22:276-298.

Perrin, W. F., J. L. Theileking, W. A. Walker, F. I. Archer and K.M. Robertson. 2010. Common bottlenose dolphins (Tursiops truncatus) in California waters: Cranial differentiation of coastal and offshore ecotypes. Marine Mammal Science. doi: 10.1111/j.17487692.2010.00442.x

Pitman, R. L., and P. Ensor. 2003. Three forms of killer whales in Antarctic waters. Journal of Cetacean Research and Management 5:131-139.

Prithiviraj, F., M. E. Pfrender, S. E. Encalada and R. Lande. 2000. Mitochondrial DNA variation, phylogeography and population structure of the Asian elephant. Heredity 84:362-372.

Read, A. J., K. W. Urian, B. Wilson and D. M. Waples. 2003. Abundance of bottlenose dolphins in the bays, sounds, and estuaries of North Carolina. Marine Mammal Science 19:59-73. 
Reilly, S. B., and P. C. Fiedler. 1994. Interannual variability of dolphin habitats in the eastern tropical Pacific. 1: Research vessel surveys, 1986-1990. Fishery Bulletin 92: $434-450$.

Rendell, L., and H. Whitehead. 2001. Culture in whales and dolphins. Behavioral and Brain Science 24:309-382.

Rigley, L. 1983. Dolphins feeding in a South Carolina salt marsh. Whalewatcher 17:3-5.

Rosel, P. E., L. Hansen and A. A. Hohn. 2009. Restricted dispersal in a continuously distributed marine species: Common bottlenose dolphins Tursiops truncatus in coastal waters of the western North Atlantic. Molecular Ecology 18:1530-1545.

Sanino, G. P., K. Van Waerebeek, M. F. Van Bressem and L. A. Pastene. 2005. A preliminary note on population structure in eastern South Pacific common bottlenose dolphins, Tursiops truncatus. Journal of Cetacean Resource Management 7:65-70.

Secchi, E. R., J. Y. Wang, B. W. Murray, C. C. Rocha-Campos and B. N. White. 2003. Population differentiation in the franciscana (Pontoporia blainvillei) from two geographic locations in Brazil as determined from mitochondrial DNA control region sequences. Canadian Journal of Zoology 76:1622-1627.

Segura, I., A. Rocha-Olivares, S. Flores-Ramírez and L. Rojas-Bracho. 2006. Conservation implications of the genetic and ecological distinction of Tursiops truncatus ecotypes in the Gulf of California. Biological Conservation 133:336-346.

Sellas, A. B., R. S. Wells and P. E. Rosel. 2005. Mitochondrial and nuclear DNA analyses reveal fine scale geographic structure in bottlenose dolphin (Tursiops truncatus) in the Gulf of Mexico. Conservation Genetics 6:715-728.

Shane, S. H., R. S. Wells and B. Würsig. 1986. Ecology, behavior and social organization of the bottlenose dolphin: A review. Marine Mammal Science 2:34-63.

Silber, G. K., and D. Fertl. 1995. Intentional beaching by bottlenose dolphins (Tursiops trunactus) in the Colorado River Delta, Mexico. Aquatic Mammals 21:193-186.

Smolker, R. A., A. F. Richards, R. C. Connor, J. Mann and P. Berggren. 1997. Spongecarrying by Indian Ocean bottlenose dolphins: Possible tool-use by a delphinid. Ethology 103:454-465.

Toth, J. L., A. A. Hohn, K. W. Able and A. M. Gorgone. 2011. Patterns of seasonal occurrence, distribution and site fidelity of coastal bottleonose dolphins (Tursiops truncatus) in southern New Jersey, U.S.A. Marine Mammal Science 27:94-110.

Toth-Brown, J., and A. A. Hohn. 2007. Occurrence of the barnacle, Xenobalanus globicipitis, on coastal bottlenose dolphins (Tursiops truncatus) in New Jersey, U.S.A. Crustaceana 80:2171-1279.

Urian, K., A. Hohn and L. Hansen. 1999. Status of the photo-identification catalog of coastal bottlenose dolphins of the western North Atlantic: Report of a workshop of catalog contributors. National Oceanic and Atmospheric Administration, Southeast Fisheries Science Center Technical Memorandum, NMFS-SEFSC-425, Beaufort, NC. 24 pp.

Urian, K., S. Hoffman, R. S. Wells and A. J. Read. 2009. Fine-scale population structure of bottlenose dolphins (Tursiops truncatus) in Tampa Bay, Florida. Marine Mammal Science 25:619-638.

VanWaerebeek, K., J. C. Reyes and J. Alfaro. 1993. Helminth parasites and phoronts of dusky dolphins Lagenorbynchus obscurus (Gray, 1828) from Peru. Aquatic Mammals 19:159169.

Vasslides, J., and K. W. Able. 2008. Fish assemblages and habitat use across a shoreface sand ridge off southern New Jersey, U.S.A. Fishery Bulletin 106:93-107.

Wang, J. Y., L. S. Chou and B. N. White. 2000. Differences in the external morphology in two sympatric species of bottlenose dolphins (Genus Tursiops) in the waters of China. Journal of Mammology 81:1157-1165.

Waring, G. T., E. Josephson, K. Maze-Foley and P. E. Rosel, editors. 2009. U.S. Atlantic and Gulf of Mexico Marine Mammal Stock Assessments-2011. NOAA Tech Memo NMFS NE 219; 598 p. Available from: National Marine Fisheries Service, 166 Water Street, Woods Hole, MA 02543-1026. Online at http://www.nefsc.noaa.gov/ nefsc/publications/ 
Wells, R. S. 2003. Dolphin social complexity: Lessons from long-term study and life history. Pages 32-56 in F. B. M. de Waal and P. L. Tyack, eds. Animal social complexity: Intelligence, culture and individualized societies. Harvard University Press, Cambridge, MA.

Wells, R. S., A. B. Irvine and M. D. Scott. 1980. The social ecology of inshore odontocetes. Pages 263-317 in L. M. Herman, ed. Cetacean behavior: Mechanisms and functions. John Wiley and Sons, New York, NY.

Wells, R. S., D. J. Boness and G. B. Rathbun. 1999. Behavior. Pages 324-422 in J. E. Reynolds, III and S. A. Rommel, eds. Biology of marine mammals. Smithsonian Institution Press, Washington, DC.

Wilber, D. H., D. G. Clarke, G. L. Ray and M. Burlas. 2003. Response of surf zone fish to beach nourishment operations on the northern coast of New Jersey, USA. Marine Ecology Progress Series 250:231-246.

Würsig, B., and S. K. Lynn. 1996. Movements, site fidelity, and respiration patterns of bottlenose dolphins on the central Texas coast. National Oceanic and Atmospheric Administration Technical Memorandum, NMFS-SEFSC-383. Miami, Florida. 111 pp.

Zolman, E. S. 2002. Residence patterns of bottlenose dolphins (Tursiops truncatus) in the Stono River Estuary, Charleston County, South Carolina, U.S.A. Marine Mammal Science 18:879-892.

Received: 12 October 2010

Accepted: 28 March 2011 